\title{
Branch wood from the lake shore settlements of Horgen Scheller, Switzerland: Evidence for economic specialization in the late Neolithic period
}

\author{
Pascal Favre ${ }^{1}$ and Stefanie Jacomet \\ Botanisches Institut der Universität, Schönbeinstrasse 6, CH-4056 Basel, Switzerland \\ Received February 11, 1998 / Accepted June 11, 1998
}

\begin{abstract}
. 596 waterlogged, uncarbonized branch wood specimens from four cultural layers of the late Neolithic lake shore site of Horgen Scheller (between 3080 and 3030 B.C.) on Lake Zürich, Switzerland, were examined. The following parameters were analysed: taxonomy, diameter and age of the twigs, cutting season, and distribution of the branches over the area as well as their distribution in the different cultural layers. The twigs were divided into the following three groups, based on differences observed in these analyses: conifers, deciduous trees with catkins, and deciduous trees without catkins. Branch diameter examinations revealed that branches of deciduous trees were thicker on average than those of conifers. While branches from deciduous trees without catkins were gathered at the age of seven years on average, those of conifers and deciduous trees with catkins were older. Waney edge analyses showed that the majority of the twigs were cut within the winter months. Among the deciduous trees without catkins there is, however, a markedly higher proportion of branches cut in summer than in the other two groups. The taxonomic examinations demonstrated that $70 \%$ of the specimens consisted of twigs of either Corylus avellana L. (hazel), Taxus baccata L. (yew), or Abies alba Mill. (silver fir), thus implying the great economic importance of these species in the settlements of Horgen Scheller. To our knowledge this is the first report that a remarkably high proportion of yew twigs $(26.8 \%)$ has been found in an analysis of subfossil twigs. The possibility is discussed that the inhabitants had specialized in obtaining yew from the region. Concentrations of wood finds, possible remains of buildings, became evident from the analyses of the distribution of the branch wood over the excavated area. A very similar spatial distribution pattern of the taxa was found through the different cultural layers. Therefore it seems likely that existing structures were reused when a new settlement was built. The data also show that the building outlines slowly moved towards land over time. A rising lake water level could have led to gradual dislocation of the settlements.
\end{abstract}

'Present address: Kantonsmuseum Baselland, Regierungsgebäude, CH-4410 Liestal, Switzerland

Correspondence to: P. Favre
Key words: Branch wood - Yew (Taxus baccala L.) Late Neolithic period - animal foddering - economic specialization.

\section{Introduction}

Recent studies have shown that Neolithic and early metal age farmers managed the wildwoods of central Europe with remarkable knowledge and technology (for example Schweingruber 1976a; Billamboz 1988; Kreuz 1988). Different woodland species were used specifically according to their properties. The lake shore settlements of the Alpine foothill region give a particularly impressive insight into this prehistoric use of wood. Within their waterlogged cultural layers various kinds of wood remains are found, for example vertical posts, large horizontal pieces of timber, and small pieces like charcoal, wood chips, and twigs. Each of these groups provides evidence of utilization by humans (Schweingruber 1976b; Bräker 1979).

Whereas vertical posts and horizontal large timbers have frequently been analysed, only a few studies have been carried out on small wood remains from the Neolithic period in Switzerland (Schweingruber 1976a,b; Pawlik and Schweingruber 1976; BaudaisLundström 1978; Bräker 1979; Jacomet 1980; Rasmussen 1991). However these studies demonstrate that huge information potential is found within this class of wood remains.

The present study concentrates upon the use of twigs during the Neolithic period. On the one hand twigs are a by-product after use of wood of any kind, on the other hand distinct accumulations of twigs can often be assigned to particular applications (Behre 1969). Schweingruber (1993) points out the significance of twigs as raw material for floor insulation, wickerwork and as roofing material. Haas and Rasmussen (1993) show the simultaneous presence of twig fragments and domestic animal faeces within the cultural layers of prehistoric sites. They suspect that twigs with catkins were used as brushwood fodder in winter. These twigs are mainly Betulaceae (birches) and Corylaceae (hazel). Evergreen 
branches of conifers were used as bedding material and winter fodder for livestock throughout historic times. High quality leaf fodder is obtained from the branches of elm, ash, maple, sycamore and lime (Waldmeier-Brockmann 1941). In the Swiss Central Alps (Lötschental, Valais) trees are still pollarded in late summer for leaf hay today (Haas and Rasmussen 1993).

At Horgen Scheller, large accumulations of twigs were found during the first excavations there (Neuweiler 1925). During the recent excavations in 1989/1990 large amounts of branch wood attracted attention again. The simultaneous appearance of sheep/goat faeces and twigs led to the idea that the twig finds could be linked to livestock economy.

Due to the scarcity of research into Neolithic animal husbandry, the extraction of the material by the excavation team was requested. In this study, twigs from these excavations were systematically analysed with the aim of gaining a better insight into Neolithic wood craft and animal husbandry regimes. Additionally the study contributes to the local vegetation history. Taking into consideration the results of analyses of botanical macrofossils (Favre, in preparation) and bones (Ebersbach, in preparation) this study should lead to a comprehensive understanding of agriculture, animal husbandry, gathering practices, and hunting at the site being examined.

\section{The site of Horgen Scheller}

The site of Horgen Scheller lies on Lake Zürich in the northeastern Swiss Plateau. Lake Zürich is elongated and stretches from southeast to northwest, an aspect which causes the two opposite shores to show local climatic differences, particularly regarding the radiation balance. Horgen Scheller lies on the less sunny southwest shore on the border between the municipalities Horgen and Oberrieden at $404 \mathrm{~m}$ asl (Fig. 1). At this place a small brook deposited a delta in a shallow bay. The settlement remains were discovered in the year 1914 in the present low water area. The land rises to the west of the site towards the Zimmerberg at $680 \mathrm{~m}$ asl, thereafter steeply descending into the gorge of the river Sihl. To the west of the Sihl gorge the Albis mountains reach 900 $\mathrm{m}$ asl, $4-5 \mathrm{~km}$ from the site. The lower basin of Lake Zürich (where the city of Zürich is today), roughly 11 $\mathrm{km}$ from the study site, and the opposite shore, which are climatically favourable, were both more densely populated during the Neolithic period than the study site (Gross and Ritzmann 1990). Several sites within the Horgen period are known, especially along the shoreline of the opposite municipality of Meilen (Ruoff 1981).

Horgen Scheller became the type site of the Horgen culture (Viollier 1924). From 1987 to 1990 further excavations took place. A connected area of about $350 \mathrm{~m}^{2}$

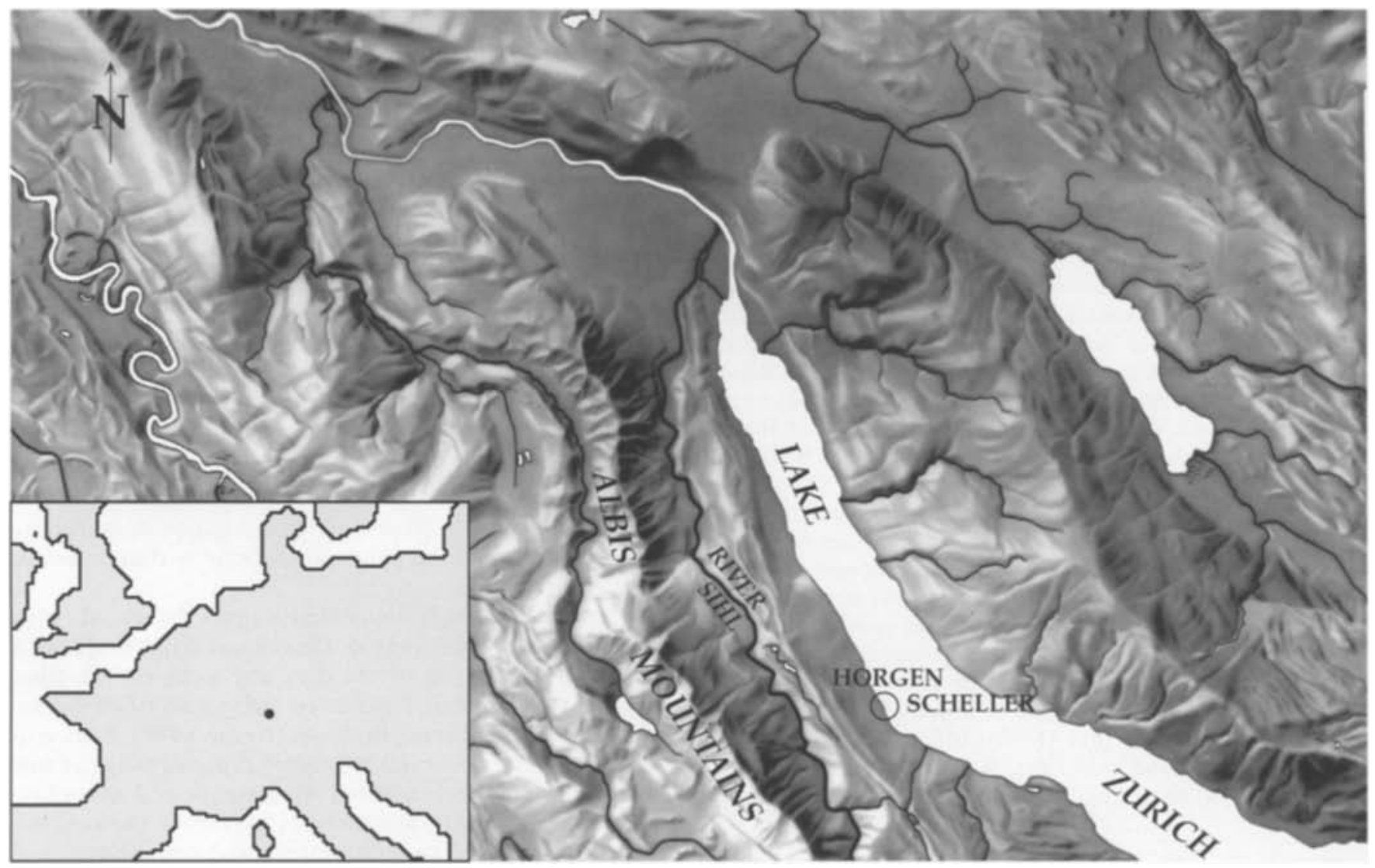

Fig. 1. Maps of (i) the lower part of the Lake Zürich region showing the Horgen Scheller site indicated by an open circle, the river Sihl, and the Albis mountains at a scale of 1:250,000, based on an original from Lehrmittelverlag des Kantons Zürich, and (ii) central Europe showing the location of the Lake Zürich region 
was investigated, which was the first time that such a big area could be examined. These excavations unearthed four to seven cultural layer complexes which were separated from each other by inorganic lake sediments. Probings showed that the excavated area lies on the edge of the former settlements which extended further to the north (see Eberli 1993).

The material examined in this study originates from the four layers $6,4,3$ and $1 / 2$. The preservation state of the individual layers is rather varied: layer 3 is the best preserved layer (thickness of $30 \mathrm{~cm}$ ), layer $1 / 2$ is the most reduced one (thickness of some millimetres). On the basis of dendrochronological analyses layers 4,3 and $1 / 2$ could be dated between 3080 and 3030 B.C. Layer 6 is older, but cannot be dated exactly. The following tree felling phases for Quercus sp. could be identified: 30513049, 3045/3044 and 3037 B.C. (Stöckli et al. 1995). The older layers 6,4 , and 3 could be assigned to the Horgen culture on the basis of pottery. Within the youngest layer, layer $1 / 2$, several ceramics belonging to the Schnurkeramik (Corded Ware) culture have been found (Eberli 1993).

\section{Methods}

The branch wood samples were collected every square metre according to a grid and coded by the excavation team. The position of each piece of wood was recorded on the grid covering the whole excavation surface, which, with the identifications, provides a map of the spatial distribution of taxa and densities over the excavation area. All branch wood pieces from each metre square were put together as a sample in a water filled plastic bag and stored at $4^{\circ} \mathrm{C}$ in a cold room.

Only those samples, which could definitely be assigned to one of the four cultural layers have been analysed. The analysed wood fragments had to follow the criteria of a typical branch form, that is round or oval diameter and length greater than width.

The diameter of each twig fragment was measured in a water saturated state with a sliding caliper (precision of \pm 0.1 $\mathrm{mm}$ ). In the case of oval branch wood pieces the largest diameter was taken.

Transverse, longitudinal and tangential thin sections from each branch wood fragment were prepared with a razor blade and examined in water under a Wild Heerbrugg M20 light microscope. The samples were then identified to taxa using the identification key, which indicates the difficulties of branch wood determination and gives an introduction to this subject (Schweingruber 1990). A piece from each branch wood was coded and stored as a reference in desalinated water at $4^{\circ} \mathrm{C}$.

The outermost annual ring (waney edge) of each individual wood piece was analysed microscopically in order to find out the time of gathering. An intact waney edge was defined by the following criteria: no visible mechanical damage, bark present at least in fragments, and no wedged out year rings visible. An outermost annual ring containing a distinct early and late wood layer indicated a completed vegetation period and therefore the wood must have been cut during the winter months (September to March). If no complete late wood layer was found in the outermost annual ring it was concluded that the branch must have been cut during the growing season (April to August; see Bräker 1979).

The annual rings of twigs with intact waney edges were also counted to find their age. Branches with absent or incomplete waney edges were not included in the age measurements since parts of the younger growth might be missing from these pieces.

Metric data were calculated by analysis of variance (ANOVA). Skewed data were transformed to obtain normal distributions (van der Veen 1992). If the transformed data were still skewed, non-parametric statistical tests were applied. To search hidden patterns in the data, correspondence analysis was applied, which had been shown to be particularly useful in analysing data of archaeobotanical tables which contain numerous zero values (Jones 1987; Lange 1990; Djindjian 1991; Jones 1991; van der Veen 1992). The following computer programs were used for these analyses and the interpretation of the data. For graphics, CLARIS MACDRAW PRO, DELTAGRAPH PRO 3.0, for statistics BMDP, JMP 2.0, for table calculations MICROSOFT EXCEL $4.0 \mathrm{~d}$ and for text MICROSOFT WORD 5.1.

\section{Results}

The identified taxa are listed together with their frequency and abundance within the different cultural layers (Table 1). Due to differences in the measured parameters, groups were created for conifers, deciduous trees with catkins, deciduous trees without catkins and others. In Table 1 each taxon is assigned to one of the groups. A list of the parameters of diameter, age, and harvesting period for each examined wood piece is available from the first author.

Analysis was done on 95 of 109 square metre samples, which each contained 1-61 twig pieces, an average of 6.27 twigs ( \pm 0.73 standard error). The number of pieces per sample shows a left skewed distribution (median $=4$ pieces $/$ sample), showing that there were more samples with few wood pieces ( $\leq 6$ pieces) than those with many ( $>6$ pieces). Finally, a total of 596 wood fragments was classified as branch wood and these were examined in more detail; a table with this information is available from the first author.

The three oldest layers $(6,4,3)$ each contributed to $30 \%$ of the specimens respectively. Only $10 \%$ of the specimens were found in the uppermost layer, horizon $1 / 2$, which was more poorly preserved.

Identification was possible for 582 of the 596 analysed twigs. 14 wood pieces $(2.3 \%)$ were only poorly preserved and no satisfactory section could be cut from these, which were listed as "indet".

The analysis revealed a wide range of taxa: one taxon could be determined to subfamily level, 14 to genus level, and eight to species level (Table 1). These 23 taxa appeared in various quantities: the values ranged from 172 pieces of Corylus avellana (hazel) and one indication for each of the taxa Viburnum sp. (guelder-rose), Salix sp. (willow), and Picea/Larix (fir/larch). The wide range of taxa found indicates a high wood diversity within the Neolithic woodlands. The varying abundances reflect the different significances of the individual taxa for the economy at Horgen Scheller. Three taxa predominate among the branch wood: $70 \%$ of the twigs consisted of either Corylus avellana (hazel) (172 indications; 28.9\%), Taxus baccata (yew) (160 indications; $26.8 \%$ ) or Abies alba (silver fir) ( 82 indications; $13.8 \%$ ), thus implying the great economic importance of these taxa. 
Table 1. Classification of the taxa into groups of (i) conifers, (ii) deciduous trees with catkins, (iii) deciduous trees without catkins and (iv) others. The frequency of taxa in all samples is also shown, and counts of taxa within each cultural layer

\begin{tabular}{|c|c|c|c|c|c|c|}
\hline Taxon/group & frequency & layer 6 & layer 4 & layer 3 & layer $1 / 2$ & total \\
\hline Abies alba Mill. / conifer & 32.6 & 5 & 32 & 37 & 8 & 82 \\
\hline Acer sp. / tree without catkins & 8.4 & 5 & 0 & 5 & 0 & 10 \\
\hline Alnus sp. / tree with catkins & 12.6 & 8 & 5 & 4 & 0 & 17 \\
\hline Betula sp. / tree with catkins & 3.2 & 1 & 2 & 0 & 0 & 3 \\
\hline Cornus sp. / tree without catkins & 3.2 & 2 & 5 & 0 & 0 & 7 \\
\hline Corylus avellana L. / tree with catkins & 56.8 & 108 & 31 & 31 & 2 & 172 \\
\hline Fagus sylvatica L. / tree without catkins & 7.4 & 6 & 4 & 2 & 0 & 12 \\
\hline Fraxinus excelsior L. / tree without catkins & 11.6 & 2 & 5 & 6 & 2 & 15 \\
\hline Hedera helix $\mathbf{L} . /$ other & 2.1 & 0 & 1 & 1 & 0 & 2 \\
\hline Ilex aquifolium L. / other & 2.1 & 4 & 0 & 0 & 0 & 4 \\
\hline Indet & 10.5 & 6 & 2 & 6 & 0 & 14 \\
\hline Picea/Larix / conifer & 1.1 & 0 & 0 & 1 & 0 & 1 \\
\hline Pomoideae / tree without catkins & 9.5 & 1 & 6 & 5 & 1 & 13 \\
\hline Populus sp. / tree with catkins & 9.5 & 2 & 9 & 1 & 0 & 12 \\
\hline Prunus sp. / tree without catkins & 6.3 & 2 & 2 & 4 & 0 & 8 \\
\hline Quercus sp. / tree without catkins & 8.4 & 3 & 2 & 12 & 0 & 17 \\
\hline Rhamnus sp. / tree without catkins & 2.1 & 1 & 0 & 3 & 0 & 4 \\
\hline Rosa sp. / tree without catkins & 2.1 & 0 & 2 & 0 & 0 & 2 \\
\hline Salix sp. / tree with catkins & 1.1 & 0 & 1 & 0 & 0 & 1 \\
\hline Sambucus sp. / tree without catkins & 1.1 & 0 & 0 & 2 & 0 & 2 \\
\hline Taxus baccata L. / conifer & 44.2 & 41 & 48 & 60 & 11 & 160 \\
\hline Ulmus sp. / tree without catkins & 17.9 & 13 & 7 & 10 & 5 & 35 \\
\hline Viburnum sp. / tree without catkins & 1.1 & 0 & 0 & 0 & 1 & 1 \\
\hline Viscum album L. / other & 2.1 & 0 & 0 & 2 & 0 & 2 \\
\hline total number & & 210 & 164 & 192 & 30 & 596 \\
\hline
\end{tabular}

The branch diameters of 593 specimens were measured. The data show a broad range. The samples ranged from $2.1 \mathrm{~mm}$ to $53.0 \mathrm{~mm}$ (average $\mathrm{x}=19.1 \mathrm{~mm} \pm 10.2$ $\mathrm{mm}$ standard deviation), except for one sample with a diameter of $93.5 \mathrm{~mm}$. This data can be obtained from the first author.

The data distribution shows two peaks (Fig. 2). The first maximum covers the diameter range $5-12.5 \mathrm{~mm}$ and the second peak comprises the range $17.5-22.5 \mathrm{~mm}$. The distribution is left skewed and strongly deviates

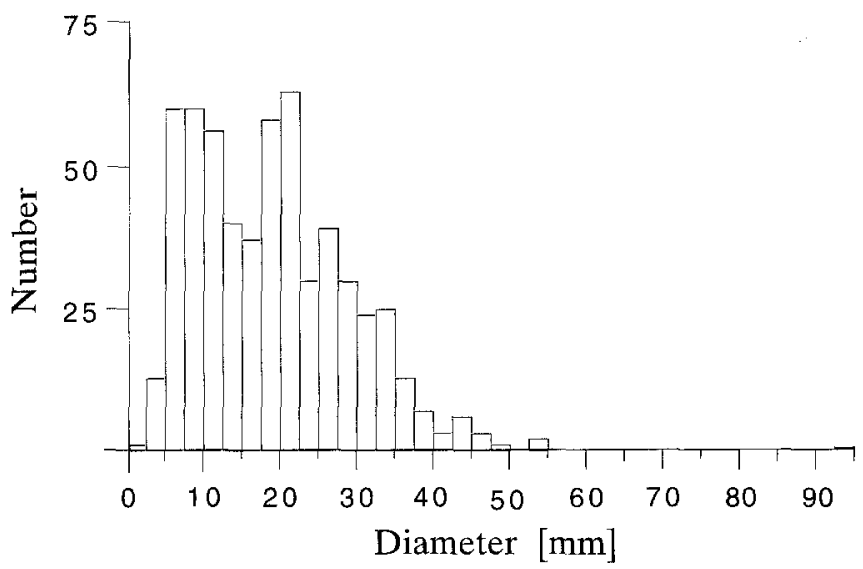

Fig. 2. Histogram of measured diameters in mm of twigs $(n=$ 593) found in the four layers examined from a normal distribution. The data were therefore root transformed, and values of taxa with more than 10 indications are shown in Fig. 3. Differences between the mean values of the individual taxa were tested with the non-parametrical Kruskal-Wallis-Test. This analysis revealed that the mean branch diameters of different tree taxa differ significantly from each other $(p<0.001)$. The average branch diameter for the taxa Abies alba (silver fir), Taxus baccata (yew), and Ulmus (elm) lie below average, ranging between $5 \mathrm{~mm}$ and $12.5 \mathrm{~mm}$. These taxa form the first maximum in the branch diameter distribution. The branch diameter for the taxa Acer sp. (maple/ sycamore), Alnus sp. (alder), Corylus avellana (hazel), Fagus sylvatica (beech), Fraxinus excelsior (ash), and Populus sp. (poplar) lie above the total average within the range of $17.5 \mathrm{~mm}$ to $22.5 \mathrm{~mm}$. These taxa contribute to the second peak of the total branch diameter distribution. The branch diameter means for Pomoideae (includes Malus, Sorbus, Pyrus, Crataegus, Cydonia) and Quercus sp. (oak) lie within the average. They are not associated with either of the two distribution maxima.

Waney edges of 239 of the 596 twigs were intact. The annual rings of 216 branches out of these were counted. Figure 4 shows that the age distribution is left skewed and contains a peak between 4 to 8 years enclosing $40 \%$ of all the branches.

A comparison of the average ages of the three groups, conifers, deciduous trees with catkins, and deciduous trees without catkins, is shown in Fig. 5. It is evident that 


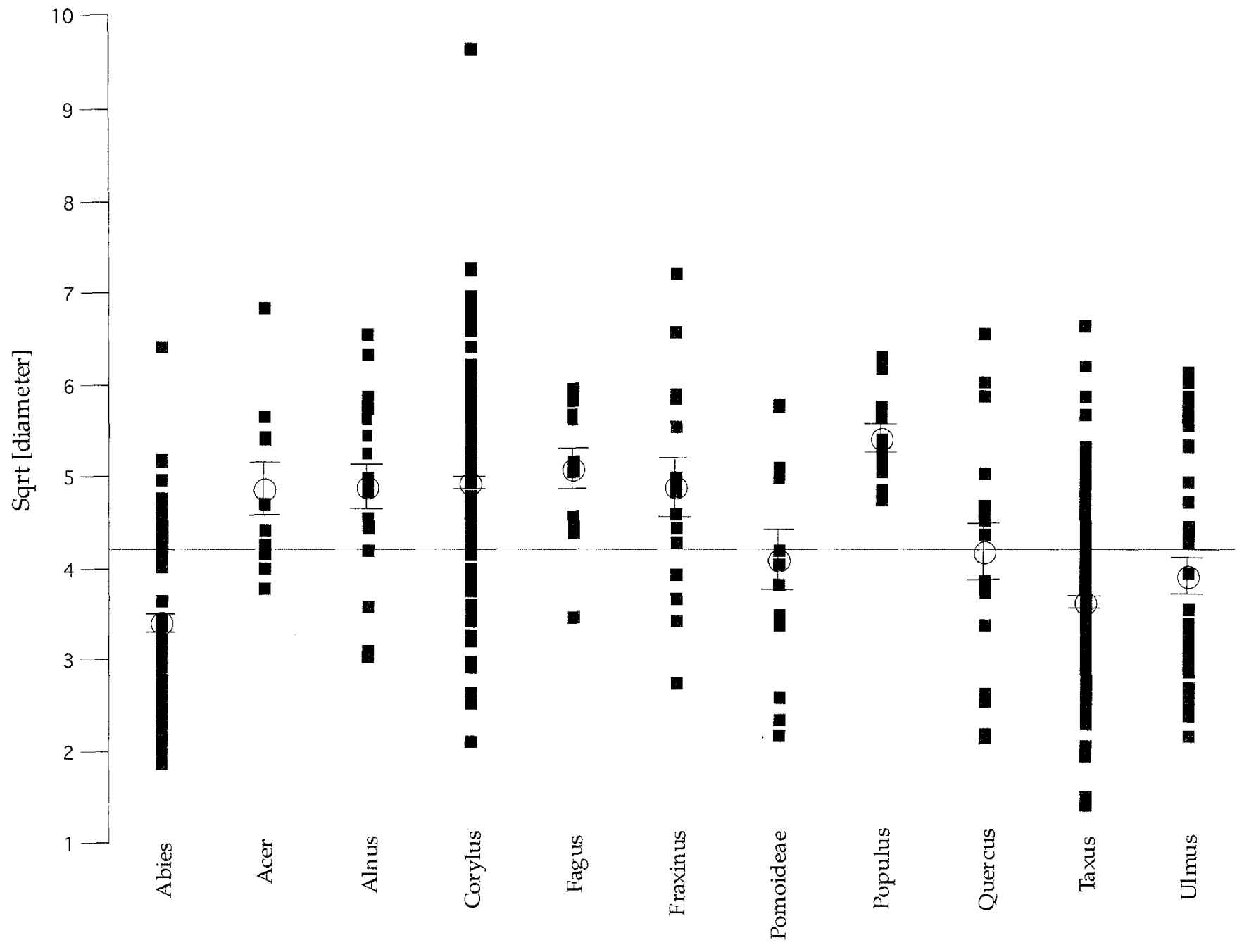

Taxon

Fig. 3. Square roots of twig diameters of the most important taxa ( $\mathrm{n} \geq 10$ ) of branchwood from the four layers examined. Small squares: individual values; open circles: group means with error bars (standard error); horizontal line: general mean (average) line

deciduous trees without catkins with an average of seven years $(\bar{x}=7 \mathrm{a}, \pm 0.76 \mathrm{se})$ were younger than deciduous trees with catkins, averaging 10 years $(\bar{x}=10$ a, \pm 0.62 se) and conifers at 12 years $(\bar{x}=12 \mathrm{a}, \pm 0.70 \mathrm{se})$. A statistical analysis using the Student's t-Test confirmed that the average age varied significantly from one group to the other, since the probability $p$ that this could be random was low $(\mathrm{p}<0.05)$. 52\% of the twigs from deciduous trees without catkins were cut between the ages of 4 to 8 years. The majority of the branches from the other two groups was cut at an older age.

Differences in the branch age could also be demonstrated between the different cultural layers, for example the age of conifers shown in Fig. 6. It can be seen distinctly that conifers of the oldest layer 6 with an average age of 16 years $(\bar{x}=16 \mathrm{a}, \pm 2.24 \mathrm{se})$ and the youngest layer 3 at 14 years $(\bar{x}=14 \mathrm{a}, \pm 1.07 \mathrm{se})$ are older on average than those within layer 4 which lies in between at eight years $(\tilde{x}=8 \mathrm{a}, \pm 1.35 \mathrm{se})$. This difference is significant (probability that these results are random $p$ $<0.05$; Tukey Kramer-HSD-Test).

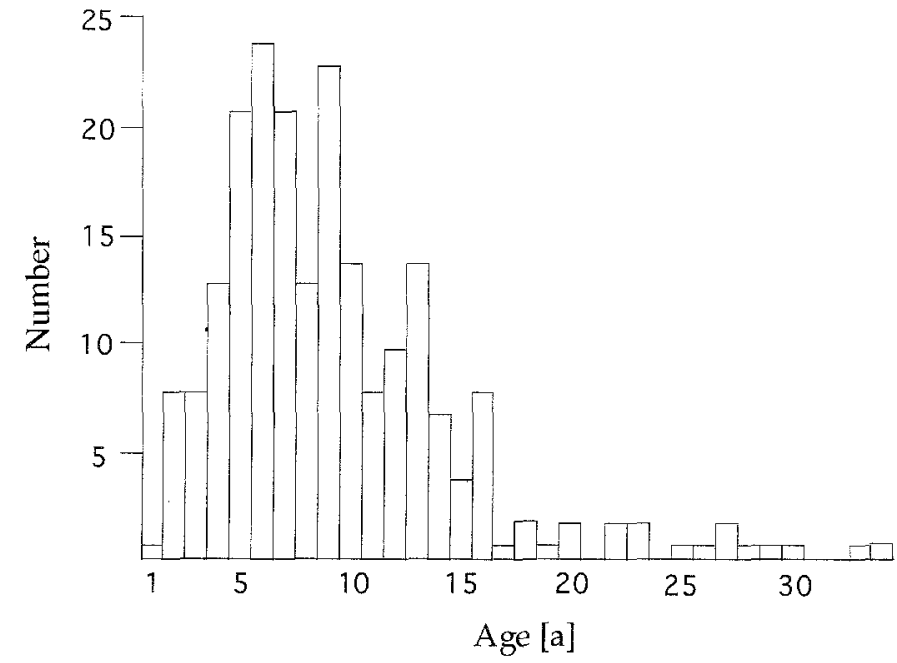

Fig. 4. Histogram of measured ages in years (a) of twigs with intact waney edges $(n=216)$ 

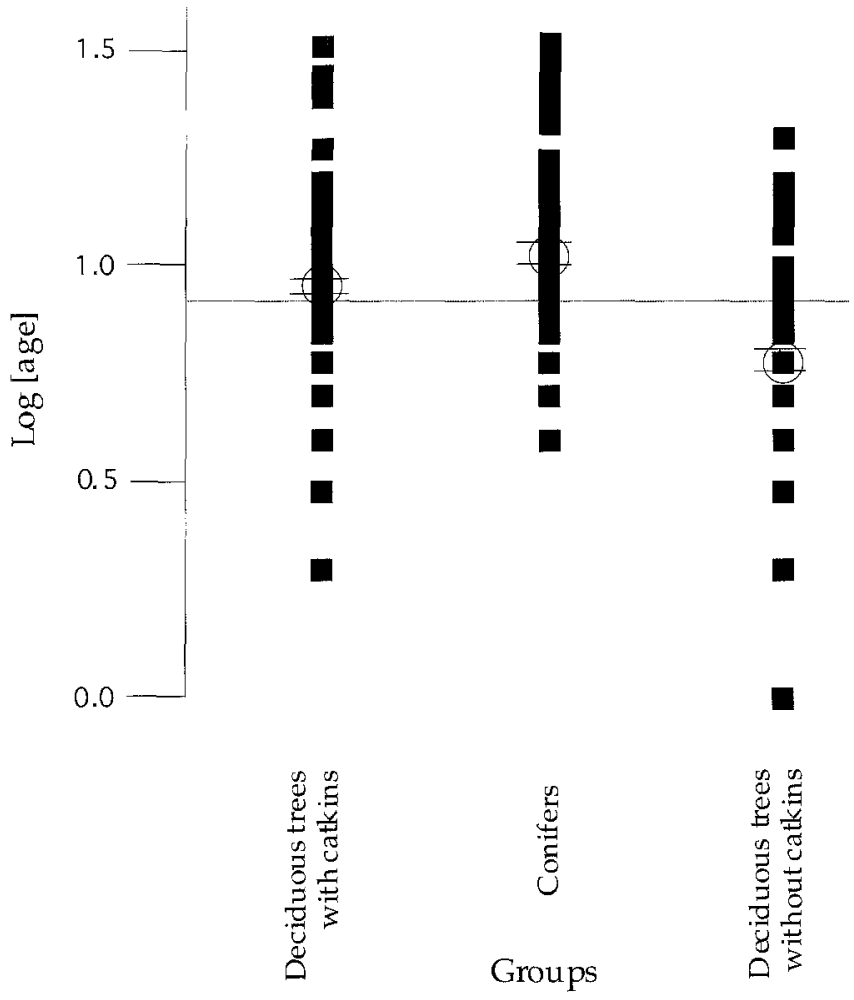

Fig. 5. Log ages of twigs classified in three groups (i) deciduous trees with catkins $(n=84)$, (ii) conifers $(n=66)$ and (iii) deciduous trees without catkins $(n=57)$. Small squares: individual values; open circles: group means with error bars (standard error); horizontal line: general mean (average) line

The time of cutting of the 239 branches with intact waney edges was determined. A distinct dominance of winter twigs is apparent: $88.3 \%$ of the branch woods showed a completed youngest year ring. Thus, they were cut during the resting period (September to March). For the remaining $11.7 \%$ branch woods the outermost annual ring was incomplete and these must therefore have been gathered during the growing season (April to August). Winter cut branches were dominant throughout all cultural layers.

The proportions of summer and winter twigs within the three groups (conifers, deciduous trees with catkins and deciduous trees without catkins) are shown in Fig. 7. More winter twigs were found among conifers and deciduous trees with catkins than among deciduous trees without catkins $(p<0.1)$.

The spatial distribution of twigs within the three cultural layers 6,4 and 3 was determined, as summarized in Fig. 8. Within the three layers the twigs were quantitatively and qualitatively heterogeneously distributed. Concentrations of twigs lay next to areas of low twig density. It is apparent that the concentrations were distributed within each individual layer in a regular pattern. In layer 6, for example, the branch accumulations are spaced equidistantly $3 \mathrm{~m}$ to $5 \mathrm{~m}$ apart from each other.

In order to allow a direct comparison between the different cultural layers, the individual concentrations were uniformly numbered I to VI within the three cultural lay- ers 6,4 and 3 . The comparison revealed that some of the twig concentrations are at the same place in the excavated area in different layers, thus keeping the same position throughout time. Layers 6 and 4 share three twig concentrations (areas $\mathrm{m}^{2}$ 804/192 [II]; 808,809/191 [III]; $803 / 196,198$ [IV]). The youngest layer 3 shares two twig concentrations with the two older layers (areas $\mathrm{m}^{2} 804$ / 192 [II]; 808, 809/191 [III]).

The oldest of the examined layers, layer 6 , contains larger branch accumulations in the concentrations IV, V, and VI on the side toward the lake, than are to be found within the two younger layers. In contrast to this, layer 3 , the youngest one, is the only layer with a twig concentration in area $I$, on the landward side. This comparison of the distribution of the concentrations within the individual cultural layers shows that the branch accumulations moved towards the land over time.

The qualitative similarity of the individual twig concentrations in each layer and of the concentrations within the different layers was examined using correspondence analysis (Fig. 9). For this analysis samples were chosen that contained (i), at least 5 examined wood pieces and (ii), taxa with a frequency greater than $5 \%$ within these samples. This selection avoided misinterpretation resulting from small samples and rare taxa. A total of 43 samples was analysed with regard to their relationship to one of the twig concentrations (I to VI) and to their affiliation to one of the cultural layers $(6,4,3,1 /$ 2 ). This analysis reveals that samples from different places of the area have different constitutions. However, in many cases those samples formed a group, which belonged to the same cultural layer. This means that some samples of the same layer are qualitatively similar. Surprisingly, the samples of some of the concentrations also constituted groups over the different layers. This is im-

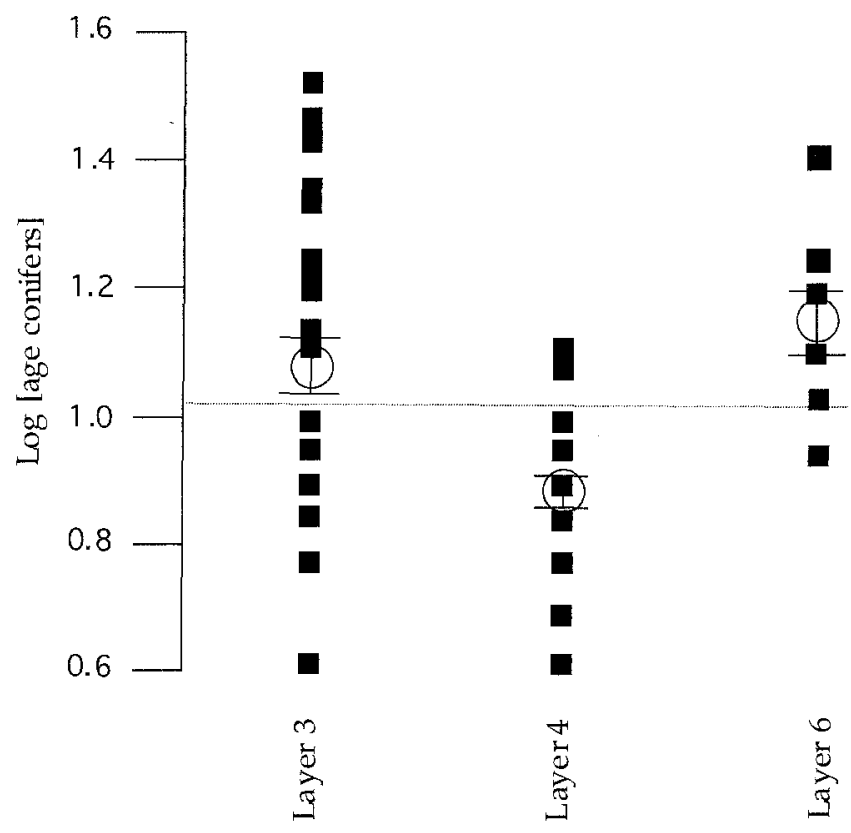

Fig. 6, Log ages of conifer twigs from the three cultural layers $6(n=8), 4(n=22)$ and $3(n=35)$. Small squares: individual values; open circles: group means with error bars (standard error); horizontal line: general mean (average) line 


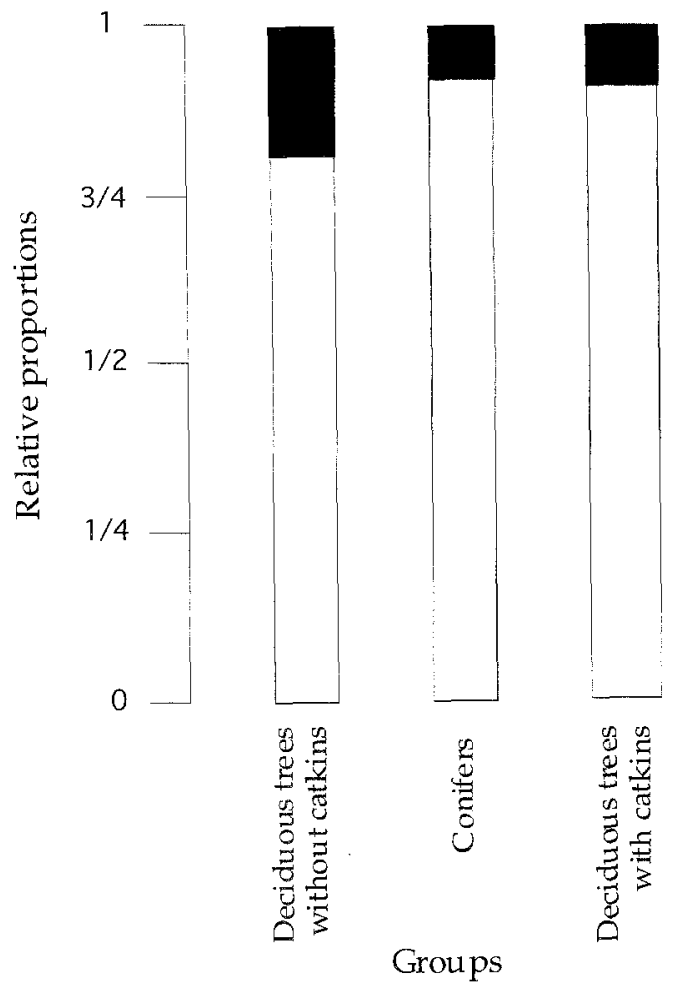

Fig. 7. Relative proportions of summer and winter twigs within the groups (i) deciduous trees with catkins $(n=87)$, (ii) conifers $(n=78)$ and (iii) deciduous trees without catkins $(n=61)$

portant since it shows that in these cases the samples have similar taxa compositions at the same place, independently of the layer. This indicates that similar settlement structures often existed in different settlement periods at a particular place.

\section{Discussion and conclusions}

The role of branch wood in the economy of the Horgen Scheller site

Corylus avellana (hazel). Hazelnuts played a central role in the nutrition of central European Neolithic communities (Gross et al. 1990). Kreuz (1990) believes that the natural hazel growth around settlements was managed.

In our study, most of the branch remains were from hazel bushes (172 identifications). This proves that not only the nuts were used, but rods from the hazel boughs as well. Hazel wood is moderately heavy and not very hard and it is therefore not a valuable timber. However, because of the flexibility of the straight grown hazel rods, it was much used, for example for hurdles (woven fencing), wattle walls or posts, and as livestock fodder.

In our analyses the majority of the hazel branches lie within the second peak of the total branch diameter distribution (Figs. 2,3). The high frequency of above average branch diameter values could be the result of the use of hazel wood for building. An alternative explanation is suggested by feeding experiments which were conducted in Lejre, Denmark: in these experiments cattle ate branches up to a thickness of approximately $25 \mathrm{~mm}$ diameter (Penack, personal communication). Because thicker branches were not eaten in this experiment, it is possible that the thick hazel branch remains found in our study may be the uneaten remains of fodder.

Deciduous trees with catkins show a higher frequency of winter branches than deciduous trees without catkins. The biology of deciduous trees with catkins gives an explanation for this result. Hazel bushes form completely developed male catkins in late autumn. Our findings suggest that branches with catkins were used as an essential protein source in late winter and early spring when stored leaf hay was scarce. Pollen evidence of alder, birch, and hazel in faeces of goats or sheep from Neolithic lake shore settlements also indicates that branches with catkins were used as a fodder in winter as these taxa pollinate in winter (Haas and Rasmussen 1993; Akeret et al. in press). Waldmeier-Brockmann (1941) describes the harvest of male hazel catkins as a fodder for horses and goats in historical times. It has been stated that poor people ate hazel catkins in order to satisfy their hunger: "...arme leut hasel zapffen...under ander frucht liessen malen, darmit sie sich des hungers erwehren könten." (Bock 1550).

The above average hazel branch diameter and the high proportion of winter hazel rods suggest that hazel branches were an important source for livestock fodder and that hazel generally played an important role in the livestock economy of the settlements at Horgen Scheller.

The remarkable stem regrowth capacity of hazel following coppicing also provides the dual revenue of nuts and rods. Hazel stumps can quickly regenerate after coppicing with straight, fast growing shoots, and hazel might therefore have been preferentially managed near settlements, compared to other taxa.

Taxus baccata (yew). In our study a large number of yew branches was found among the late Neolithic samples from around 3000 B.C. at Horgen Scheller (160 identifications; $26.8 \%$ of all twigs). To our knowledge this has never been shown from any site before. From the literature it seems obvious that yew could not have been widespread in the Swiss Plateau region after 3800 B.C.. Yew shows a tendency to reduction in the Seedorfsee region (western Swiss Plateau) at that time (Haas and Richoz 1995) and it was not traceable in most of the pollen analyses from the Lake Zürich region (Heitz-Weniger 1976; Hufschmid 1983; Erny-Rodmann 1996). In the eastern Swiss Plateau region, the species has only been found at Wallisellen near Zürich, between 6660 and 4660 cal B.C. (Haas 1996). The scarce appearance of yew in the pollen analyses may be due to its restricted distribution resulting from its weak competitive ability compared with other trees. Despite its wide ecological range, yew grows slowly and can therefore only persist in special niches where fast growing species are disadvantaged (Scheeder 1994). Today these habitats are mainly steep and shaded slopes. Within the Lake Zürich 


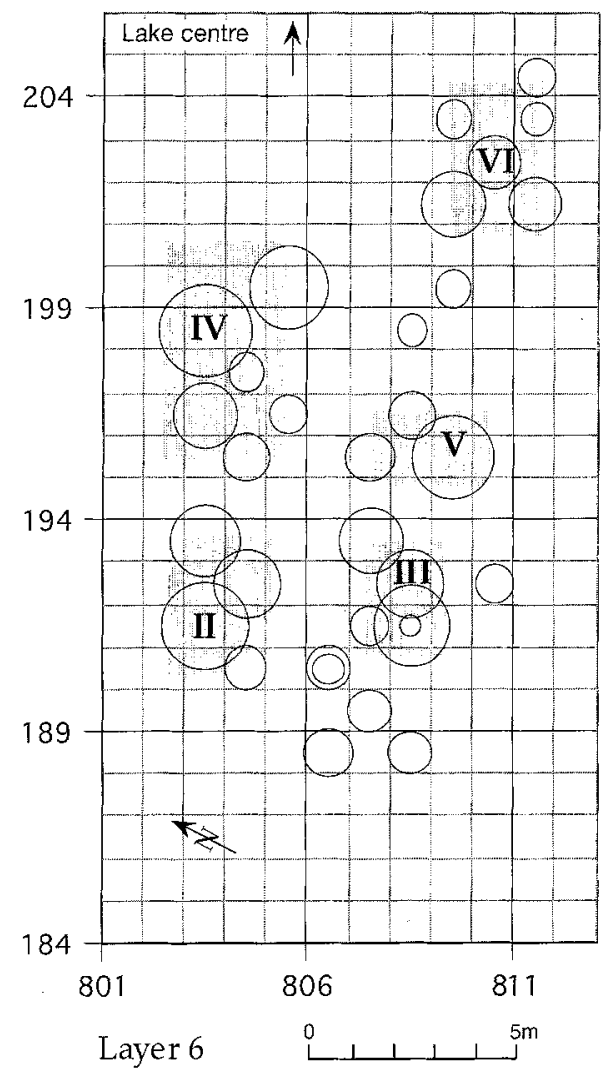

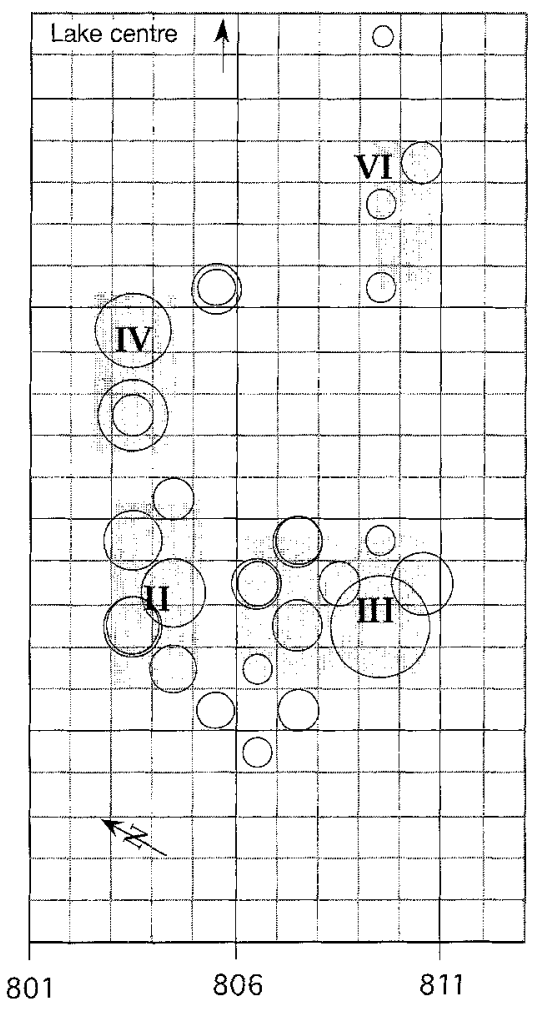

Layer 4

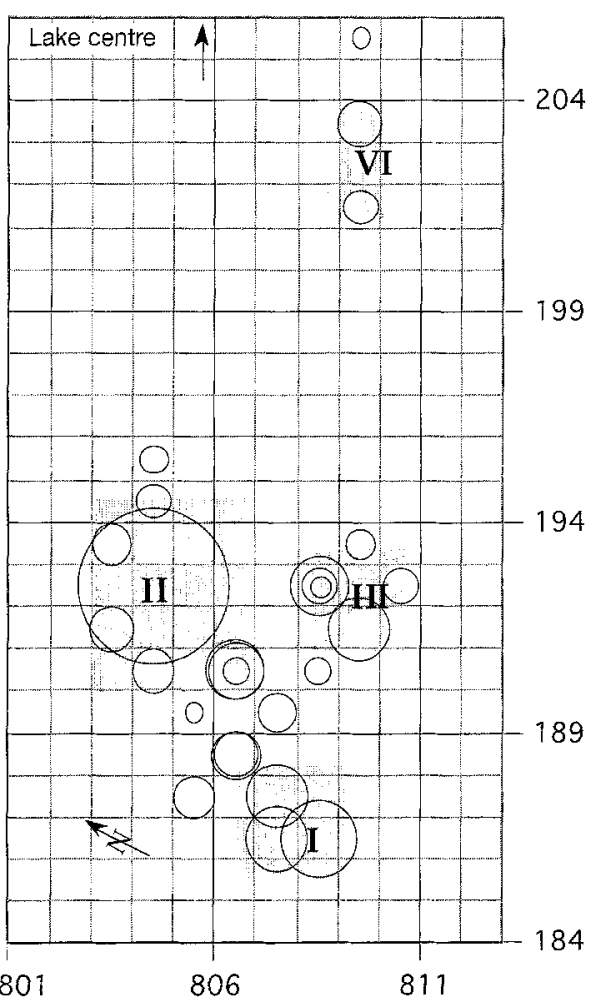

Layer 3

Fig. 8. Spatial distribution of the twig finds within each of the individual cultural layers 6,4 , and 3 . The size of the circles is proportional to the number of twigs found in a particular squaremeter. From this several concentrations (I to VI) become apparent

region such habitats are found along the Sihl gorge and the northerly slopes of the Albis chain, the Uetliberg region, near the study site. The Üetliberg region is even now one of the two centres of yew distribution in the Swiss Plateau (Wohlgemut and Kull 1995).

The high frequency of yew wood finds in our study contrasts with the fact that yew was not very widespread in the Swiss Plateau region. Our findings therefore indicate that yew must have played an important economic role at Horgen Scheller. This suggestion is confirmed by the archaeological analyses of excavated material from Horgen Scheller by Eberli (1993): Among 43 wooden tools found, eight $(18.6 \%$ ) were made from yew. Among the large horizontal pieces of timber, $5.1 \%$ were of yew. Among the 1952 posts, none was made of yew. Because of these results we suppose that yew was not used for house building, but that it was used for special applications instead, such as making weapons such as bows, and tools. The large number of yew branches found in our study probably results from the felling of yew trees and arose during the work on the timber. However it is not clear what yew twigs were used for. Yew is listed among the most poisonous central European plants (Binz and Heitz 1986). All parts of the tree are poisonous with the exception of the aril. Particularly high poison concentrations are contained in wilting needles. According to Kühnert (1991), 10-12 g yew needles per kg body weight are lethal for cloven-hoofed animals. In contrast to this,
Sebald et al. (1990) state that yew is not poisonous for ungulates. The fact that browsing of young trees by deer is very common also confirms this suggestion (Steiger 1994). In general, poisonous plants were used less carefully in the past (Willinger, personal communication) and the use of yew twigs as a winter fodder is to be taken into account. The contradictory information concerning the lethality of yew for ungulates leaves this question open.

The results of our branch diameter analyses as well as the analyses of the spatial distribution also leave the possibility open that yew branches could have been used as bedding and insulation material (see below).

Abies alba (silver fir). Between the seventh and fifth millennia B.C. mixed woods of Abies and Fagus began to displace the Atlantic mixed-oak woodland taxa (Quercus, Ulmus, Tilia). These woods were predominant throughout the Lake Zürich region (Erny-Rodmann et al. 1997). Abies had a strong expansion tendency between 4900 and 4500 cal B.C., and woods in the lowlands around the lake at that time were mainly of Ulmus and Abies (Erny-Rodmann 1996).

Abies twigs could have been used as livestock fodder, due to the non-poisonous and soft needles, as well as for insulation and floor material in living quarters. Abies twigs are still used as fodder for large herbivores in 
Basel Zoo today (personal observation). In historic times, silver fir branches were brought into the settlements either as fodder or as litter (Brockmann-Jerosch 1918; Waldmeier-Brockmann 1941). It is also known that the brushwood, the so called Kris or Grass, was used throughout the alpine region (Waldmeier-Brockmann
1941). In our branch wood analyses Abies was the third most abundant taxon ( 82 finds), it may therefore have been used as fodder or litter. However the result that the analysed Abies branch diameters were on average smaller than those of deciduous trees suggests that silver fir played a minor role as fodder: if small twigs were

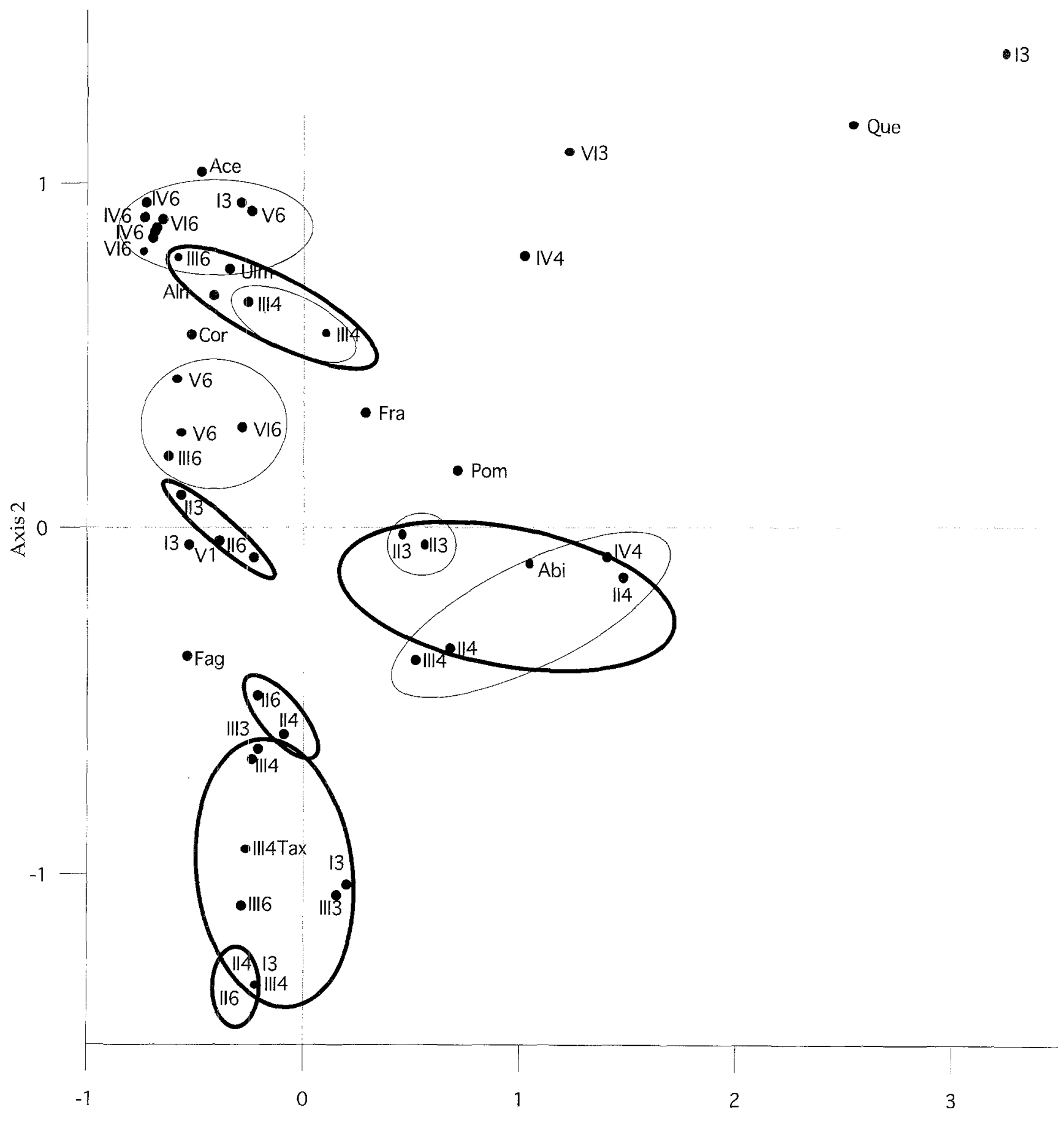

Axis 1

Fig. 9. Correspondence analysis of samples that contained at least five pieces of wood, and taxa with a frequency of $>5 \%$ within these samples (Abi: Abies alba; Ace: Acer sp.; Aln: Alnus sp.; Cor: Corylus avellana; Fag: Fagus sylvatica; Fra: Fraxinus excelsior; Pom: Pomoideae; Que: Quercus sp.; Tax: Taxus baccata; Ulm: Ulmus sp.). Thin lines surround grouped samples from the same cultural layer (layers numbered 6, 4, 3, 1); thick lines surround grouped samples from the same twig concentration (I to VI). Variance accounted for $20.7 \%$ (axis 1) and $20.2 \%$ (axis 2) 
used in that way they would have been eaten up completely (see hazel). Since no Abies needle remains were found in the sheep/goat droppings from Horgen Scheller (Akeret and Jacomet 1997), although such fragments were abundant in similar samples from the Neolithic lake shore site of Arbon Bleiche 3 on Lake Constance (Bodensee) (Akeret et al. in press), it is considered unlikely that Abies was fed to small livestock at Horgen Scheller. We therefore propose that the fir twigs found at the Horgen Scheller site were mainly used in the living quarters. As will be discussed below, the branches might have been stacked up as a bedding material in the sleeping quarters.

Deciduous trees without catkins. Most of the twigs from deciduous trees without catkins was harvested in winter. However the proportion of twigs harvested during the summer months was higher in this group than among the deciduous trees with catkins and conifers. From this result it seems reasonable to suggest that deciduous trees without catkins could have been used for leaf hay. Most of the trees which are frequently pollarded even today are deciduous trees without catkins (Fraxinus, Ulmus, Acer). The gathering of leaf hay is the only woodland management activity which must be done in summer, and nowadays takes place in late summer. Wood growth ends between August and September, and so twigs gathered by that time were classified as "winter" in our study, because they show a complete outermost annual ring under the microscope. Our classification as winter or summer is based on the only preserved feature that allows the distinction of the wood growth phase. However for the period of the end of growth during the year this classification cannot be accurate. It is therefore probable that remains of leaf hay not only occur within samples classified as "summer" but that some remains are classified as "winter". Leaf hay production must therefore have been economically even more important than our analysis of gathering periods suggests.

Branches of deciduous trees without catkins were younger on average, at four to eight years, than branches of the other species. One explanation for this is that deciduous trees without catkins were pollarded at regular four to eight year intervals. This cycle is usual for the production of leaf hay today.

\section{Comparison of the branch wood spectra in the individual cultural layers}

The branch wood spectra in the individual cultural layers of the Horgen Scheller site show a decline in Corylus with time, while at the same time the evidence of Taxus and Abies increases. This indicates that conifers became economically more important during the examined phases. The results of the age determination of Taxus and Abies branches within the three layers support this interpretation: branches derived from layer 4 are younger than those from the layers 6 and 3 (see Fig. 6). We suggest that the conifer resources gradually decreased during the settlement periods: during the early phases of colonization there were enough trunks and branches (layer 6). Coincidentally the observed branch age is above average. The settlers of the following period were faced with scarcer timber because of the human impact during the preceding period and were thus forced to fell younger trees (layer 4). In the most recent of the examined periods the conditions were even worse and the settlers had to search in more distant woods for mature wood in order to satisfy the demand for yew timber and fir brushwood (layer 3). According to this hypothesis, as time went by, timber was felled further and further inland from the lake shore settlement. The advantages of the site for settlement probably included suitable places for driving in posts for house platforms, protection, water sources, transport routes, and fishing waters, and these seem to have outweighed the disadvantages, such as the increased effort needed for gathering the raw material from a distance. The choice of the lake shore as the settlement site was therefore crucial for the organization of the human community. The use of conifer branches was a sustainable influence on the woods, as has been described by Jugowitz (1908) "Im Herbst beginnt dann zwecks 'Grassgewinnung' die alte Baumschinderei, deren Erfolg wir in astarmen, kernfaulen, steigmastähnlichen Stämmen genügsam kennen." (This quotation describes how the cutting of branch wood leads to stem rotting and poorly branched trees). In the present study, evidence was found for the utilization of branches by humans and in view of the factors discussed one can presume that human populations had a marked influence on the woodlands as early as Neolithic times. Dendrochronological studies on posts are necessary to gain further evidence for this influence. It has been shown, for instance, that the detailed analysis of data from annual rings can allow the detection of pollarding (Haas and Schweingruber 1993) and woodland management practices such as coppicing (Bauer 1990; Billamboz 1996). To date, such examinations have not been carried out on posts from the Lake Zürich region.

Hypothetical model for the economic specialization at Horgen Scheller

The low proportion of summer branches within the total wood shows that woodland management was done mainly in the winter. This result is in accordance with the annual calendar of agriculture (Jacomet et al. 1989).

Trees that grew at the settlement site itself formed only a part of the analysed material. According to present phytosociological knowledge several of the taxa found, such as Abies and Taxus, did not grow at the settlement site, but further away. These species were much more frequent in our analysis than those of species that grew directly at the settlement site such as Betula and Salix. These results show that Neolithic people chose to obtain certain trees from a distance away from the occupation site. As mentioned before, our investigations also prove that the use of Taxus must have been of particular importance for the economy of the Horgen Scheller site. We therefore propose the following economic model for Horgen Scheller: Yew trees with branches were felled 
and dragged from the woods to the settlement. There the branches were removed and the trunks stored as horizontal large timbers. The timber was transported to other settlements for use. According to our model, Horgen Scheller was a producer site that was at least partly specialized in obtaining and trading yew.

Pollen analysis has shown that yew was not generally widespread in the Neolithic period. A number of prehistoric weapons and tools which were made from yew wood have been found (Neuweiler 1905; Bortenschlager et al. 1992), evidence that suggests that yew wood was an important raw material. Yew habitats must therefore have attracted prehistoric people and influenced the economy. Our model could also explain why, although yew wood remains are found in the lower Lake Zürich region, only little evidence of yew pollen has been found in this region (Erny-Rodmann 1996). Since yew seems not to have grown in the surrounding areas of the lower Lake Zürich region, it is possible that this area was a consumer site for this species.

\section{Settlement structures}

A comparison of the branch wood accumulations in layer 3 (Fig. 8) with the plan of clay deposits in the same layer (Eberli 1993) shows that the branch wood accumulations were adjacent to the clay pockets. Clay pockets could be the remains of floors within the housekeeping areas of the houses (Eberli, personal communication) and the finds of branch wood accumulations close to clay pockets suggests that twigs may have been used inside the houses. The analysis of the spatial branch wood distribution showed that branch wood concentrations were at a certain distance from each other. A pattern like this is to be expected, if twigs were used inside the houses.

A comparison of the location of the branch wood concentrations with the areas of animal bone accumulations found by Ebersbach (in preparation) shows that the bone is in different positions within the same layers. Bone accumulations generally indicate waste deposits, which were most probably outside the houses. Since the branch wood concentrations are found in areas different to those of the bone accumulations, it is most likely that twigs indicate inside areas of houses. It is possible that branches were used as a insulation and padding material in the living and sleeping areas of the houses, as is known from the Athabasbaka Indians in Alaska up to the recent past: "The interior (of a sleeping quarter) was covered with a thick layer of silver fir twigs upon which several fur blankets were spread out" (Wallis 1993). Additionally the branch wood could also have served as litter or fodder.

It has not been possible to reconstruct house outlines by using dendrochronological analyses of the Horgen Scheller material up to now (Eberli 1993). The distribution pattern of branch wood accumulations, their occurrence together with clay deposits, and the fact that bones were found in different areas are the first hints to the position of buildings within the settlement. If the branch wood concentrations are considered as the remains of buildings, three to six houses in two rows at right angles to the shore line could be distinguished. Between both rows a path might have led in the direction of the shoreline.

Some of the branch wood accumulation centres which were furthest from the middle of the lake occurred at exactly the same horizontal position throughout the different vertical layers (Fig. 8), and showed qualitative similarities with each other. A possible explanation for this result could be "conservative renewal" of the villages, in which structures of an abandoned settlement were reused during the reconstruction of a new village. This would implicate that similar activities were performed in the same areas during various settlement periods and that human labour as well as material resources were used carefully.

Our analysis of the distribution of twigs over the excavated area also revealed that the branch wood concentrations which were closest to the lake centre disappeared with time (Fig. 8), while at the same time, new branch wood concentrations appeared further from the lake centre. A rising lake level probably forced the settlers to settle nearer land in successive periods. Eberli (1993) suggested that the rising lake forced the settlers to abandon the site, according to archaeological evidence. Our results support this thesis.

Acknowledgements. The authors are indebted to the archaeologists Dr Ulrich Ruoff und Andreas Zürcher for providing the study material and to the Archaeological Service of the Canton Zürich and the foundation "Mensch-Gesellschaft-Umwelt" (Project No. 95/19), University of Basel, for providing financial support. We wish to thank Örni Akeret, Ulrich Eberli, Prof Dr Jörg Schibler, Dr Angela Schlumbaum, Esther Schreier and Christine Ziegler for interesting discussions and their support. Furthermore the authors thank Renate Ebersbach, Dr Erika Hiltbrunner, and Andreas Tinschert for critically reading the manuscript and many helpful suggestions.

\section{References}

Akeret Ö, Jacomet S (1997) Analysis of plant macro fossils in goat/ sheep faeces from the Neolithic lake shore settlement of Horgen Scheller - an indication of prehistoric transhumance? Veget Hist Archaeobot 6: 235-239

Akeret $\ddot{\mathrm{O}}$, Haas $\mathrm{JN}$, Leuzinger $\mathrm{U}$, Jacomet $\mathrm{S}$ (in press) Plant macrofossils and pollen in goat/sheep faeces from the Neolithic lake shore settlement Arbon-Bleiche 3, Switzerland

Baudais-Lundström K (1978) Plant remains from a Swiss neolithic lakeshore site: Brise Lames, Auvernier. Ber Deutsch Bot Ges 91: $67-83$

Bauer S (1990) Siedlungsarchäologische Untersuchungen im bayrischen Altmoränengebiet - die Talrandsiedlung Pestenacker. Ber RGK 71: 334-354

Behre KE (1969) Der Wert von Holzartenbestimmungen aus vorgeschichtlichen Siedlungen (dargestellt an Beispielen aus Norddeutschland). Neue Ausgrab Forsch Niedersachsen 4: $348-358$

Billamboz A (1988) Jahresringe im Bauholz. In: Planck D (ed) Archäol Württemberg: 515-529

Billamboz A (1996) Tree Rings and Pile Dwellings in Southwestern Germany: Following in the Footsteps of Bruno Huber. Radiocarbon 1996: 471-483

Binz A, Heitz C (1986) Schul- und Exkursionsflora für die Schweiz. Schwabe, Base! 
Bock H (1550) Teutsche Speißkammer. Wendel Rihel, Strassburg Bortenschlager S, Kofler W, Oegg1 K, Schoch W (1992) Erste Ergebnisse der Auswertung der vegetabilischen Reste vom Hauslabjochfund. In: Höpfel F, Platzer W, Spindler K (eds) Der Mann im Eis. Band 1. Veröff Univ Innsbruck 187: 307-312

Bräker OU (1979) Angewandte Holzanalyse. Beitrag zur Rekonstruktion der Umwelt neolithischer Ufersiedlungen in Feldmeilen-Vorderfeld. Haupt, Bern

Brockmann-Jerosch H (1918) Das Lauben und sein Einfluss auf die Vegetation der Schweiz. Jahresber Geogr Ethnogr Ges Zürich 1917/18: 3-20

Djindjian F (1991) Méthodes pour l'archéologie. Colin, Paris

Eberli U (1993) Horgen Scheller. Neolithische Ufersiedlungen am Zürichsee. Lizentiatsarbeit, Universität Zürich

Erny-Rodmann C (1996) Von der Urlandschaft zur Kulturlandschaft. Pollenanalytische Untersuchungen an drei Uferprofilen aus dem Zürcher Seefeld zu anthropogenen Vegetationsveränderungen seit dem Mesolithikum bis ins ausgehende Neolithikum. Dissertation, Universität Basel

Erny-Rodmann C, Gross-Klee E, Haas JN, Jacomet S, Zoller H (1997) Früher (human impact» und Ackerbau im Übergangsbereich Spätmesolithikum-Frühneolithikum im Schweizerischen Mittelland. Jahrb Schweizr Ges Ur Frühgesch 80: 27-56

Gross E, Ritzmann C (1990) Die neolithischen und bronzezeitlichen Siedlungen im Zürcher Seefeld. In: Die ersten Bauern Bd. 1. Schweizerisches Landesmuseum, Zürich, 161-176

Gross E, Jacomet S, Schibler J (1990) Stand und Ziele der wirtschaftsarchäologischen Forschung an neolithischen Uferund Inselsiedlungen im unteren Zürichseeraum (Kt. Zürich, Schweiz). In: Schibler J, Sedlmeier J, Spycher H (eds) Festschrift Hans R. Stampfli. Helbing und Lichtenhahn, Basel, pp 77.100

Haas JN (1996) Pollen and plant macrofossil evidence of vegetation change at Wallisellen-Langachermoos (Switzerland) during the Mesolithic-Neolithic transition 8500 to 6500 years ago. Diss Bot 267. Cramer, Berlin

Haas JN, Rasmussen P (1993) Zur Geschichte der Schneitel- und Laubfutterwirtschaft in der Schweiz - eine alte Landwirtschaftspraxis kurz vor dem Aussterben. In: Brombacher C, Jacomet S, Haas JN (eds) Festschrift Zoller. Diss Bot 196: 469-489. Cramer, Berlin

Haas JN, Schweingruber FH (1993) Wood anatomical evidence of pollarding in ash stems from the Valais, Switzerland. Dendrochronologia 11: $35-43$

Haas JN, Richoz I (1995) Flora und Vegetation im Schweizer Mittelland und im Jura. In: Stöckli WE, Niffeler U, GrossKlee E (eds) Die Schweiz vom Paläolithikum bis zum frühen Mittelalter, SPM II. Schweizerische Gesellschaft für Ur- und Frühgeschichte, Basel, pp 58-72

Heitz-Weniger A (1976) Pollenanalytische Untersuchungen an drei prähistorischen Siedlungsplätzen im untersten Zürichsee (Schweiz). Dissertation, Universität Basel

Hufschmid N (1983) Pollenanalytische Untersuchungen zur postglazialen Vegetationsgeschichte rund um den Zürichsee anhand von anthropogen unbeeinflussten Moor- und Seesedimenten. Dissertation, Universität Basel

Jacomet S (1980) Botanische Makroreste aus den neolithischen Seeufersiedlungen des Areals "Pressehaus Ringier" in Zürich (Schweiz). Stratigraphische und vegetationskundliche Auswertung. Vierteljahrsschr Naturforsch Ges Zürich 125: 73-163

Jacomet S, Brombacher C, Dick M (1989) Archäobotanik am Zürichsee. Ackerbau, Sammelwirtschaft und Umwelt von neolithischen und bronzezeitlichen Seeufersiedlungen im Raum Zürich. Orell Füssli, Zürich

Jones $G$ (1987) A statistical approach to the archaeological identification of crop processing. J Arch Sci 14: 311-323
Jones $G$ (1991) Numerical analysis in archaeobotany. In: Zeist W van, Wasylikowa K, Behre KE (eds) Progress in old world palaeoethnobotany. Balkema, Rotterdam, pp. 63-80

Jugowitz RA (1908) Wald und Weide in den Alpen. Wien

Kreuz A (1988) Holzkohle-Funde der ältestbandkeramischen Siedlung Friedberg-Bruchenbrücken: Anzeiger für Brennholz-Auswahl und lebende Hecken? In: Küster $\mathbf{H}$ (ed) Der prähistorische Mensch und seine Umwelt. Forsch Ber Vor Frühgesch Baden-Württemberg 31: 139-153. Theiss, Stuttgart

Kreuz A (1990) Die ersten Bauern Mitteleuropas - eine archäobotanische Untersuchung zu Umwelt und Landwirtschaft der ältesten Bandkeramik. Analecta Praehist Leidensia 23. Leiden

Kühnert M (ed) (1991) Veterinärmedizinische Toxikologie. Allgemeine und klinische Toxikologie. Grundlagen der Ökotoxikologie. Fischer, Jena

Lange AG (1990) De Horden near Wijk bij Duurstede. Plant remains from a native settlement at the Roman frontier: a numerical approach. ROB, Amersfoort

Neuweiler E (1905) Die prähistorischen Pflanzenreste Mitteleuropas. Vierteljahrsschr Naturforsch Ges Zürich 50: 1-110

Neuweiler E (1925) Pflanzenreste aus den Pfahlbauten vom Hausersee, Greifensee und Zürichsee. Vierteljahrsschr Naturforsch Ges Zürich 70: 225-232

Pawlik B, Schweingruber FH (1976) Die archäologisch-vegetationskundliche Bedeutung der Hölzer und Samen in den Sedimenten der Seeufersiedlung Horgen "Dampfschiffsteg". Jahrb Schweiz Ges Ur Frühgesch 59: 77-91

Rasmussen P (1991) Leaf-foddering of livestock in the Neolithic: Archaeobotanical evidence from Weier, Switzerland. J Danish Archaeol 8: 51-71

Ruoff U (1981) Die Ufersiedlungen an Zürich- und Greifensee. Helvetia Archaeol 45/48: 19-61

Scheeder T (1994) Die Eibe (Taxus baccata L.): Hoffnung für ein fast verschwundenes Waldvolk. IHW-Verlag, Eching

Schweingruber FH (1976a) Botanische Untersuchung der Holzreste aus Egolzwil 5. In: Wyss R (ed) Archäologische Forschungen, das jungsteinzeitliche Jäger-Bauerndorf von Egolzwil 5 im Wauwilermoos. Schweizerisches Landesmuseum, Zürich, 151-162

Schweingruber FH (1976b) Prähistorisches Holz. Die Bedeutung von Holzfunden aus Mitteleuropa für die Lösung archäologischer und vegetationskundlicher Probleme. Haupt, Bern

Schweingruber FH (1990) Mikroskopische Holzanatomie. Eidgenössische Forschungsanstalt für Wald, Schnee und Landschaft, Birmensdorf

Schweingruber FH (1993) Jahrringe und Umwelt - Dendroökologie. EidgenössischeForschungsanstalt für Wald, Schnee und Landschaft, Birmensdorf

Sebald O, Seybold S und Philippi G (eds) 1990. Die Farn- und Blütenpflanzen Baden-Württembergs. Bd. 1. Ulmer, Stuttgart

Steiger P (1994) Wälder der Schweiz. Ott, Thun

Stöckli WE, Niffeler U, Gross-Klee E (eds) (1995) SPM II: Neolithikum. Verlag Schweizerische Gesellschaft für Ur- und Frühgeschichte, Basel

Veen $M$ van der (1992) Crop Husbandry Regimes. Sheffield Archaeol Monogr 3. Sheffield

Viollier D (1924) P fahlbauten. 10. Bericht. Mitt Antiq Ges Zürich 29: $184-186$

Waldmeier-Brockmann A (1941) Sammelwirtschaft in den Schweizer Alpen. Helbing und Lichtenhahn, Basel

Wallis V (1993) Zwei alte Frauen. Klein, Hamburg

Wohlgemuth T, Kull P (1995) Ist die Eibe am Ütliberg häufig?Stichprobenerhebung als Ergänzung floristischer Inventare. Informationsbl Forschungsbereich Landschaftsökol WSL 26: $1-2$ 